\title{
FSCN1 Gene
}

National Cancer Institute

\section{Source}

National Cancer Institute. FSCN1 Gene. NCI Thesaurus. Code C101605.

This gene is involved in actin filament assembly. 